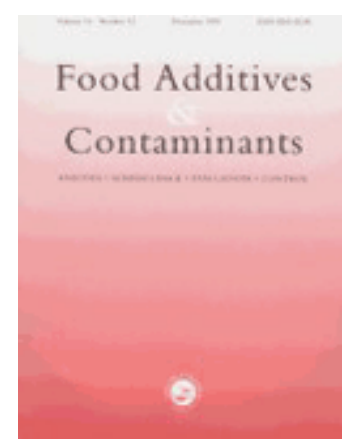

\title{
Confirmatory analysis of steroids in muscle using liquid chromatography - tandem mass spectrometry
}

\begin{tabular}{|r|l|}
\hline Journal: & Food Additives and Contaminants \\
\hline Manuscript ID: & TFAC-2010-345.R1 \\
\hline Manuscript Type: & Original Research Paper \\
\hline $\begin{array}{r}\text { Date Submitted by the } \\
\text { Author: }\end{array}$ & 09-Dec-2010 \\
\hline Complete List of Authors: & $\begin{array}{l}\text { Pedersen, Mikael; DTU Food, Food Chemistry } \\
\text { Andersen, Jens; DTU Food, Food Chemistry }\end{array}$ \\
\hline Methods/Techniques: & Chromatography - LC/MS, Method validation \\
\hline Additives/Contaminants: & Veterinary drug residues - anabolic steroids \\
\hline Food Types: & Animal products - meat \\
\hline
\end{tabular}

\section{SCHOLARONE \\ Manuscripts}


Confirmatory analysis of steroids in muscle using liquid chromatography -

\section{2 tandem mass spectrometry}

4 Mikael Pedersen and Jens Hinge Andersen

6 National Food Institute (DTU-FOOD), Mørkhøj Bygade 19, DK-2860 Søborg, Denmark

8 Abstract:

9 A method is described for screening and confirmation of synthetic and endogenous steroids in

10 muscle tissue. The method is sensitive, selective, rapid and the consumption of organic solvents is

11 low, compared to previously published methods. The procedure involves hydrolysis, defattening

12 with heptane and final clean up with SPE using C18 cartridge. After filtration the analytes are

13 analysed by LC/MS/MS, and quantification is performed using deuterated internal standards.

14 Decision limits $(\mathrm{CC} \alpha)$ varied from 0.02 to $0.33 \mu \mathrm{g} \mathrm{kg}^{-1}$ and the detection capabilities $(\mathrm{CC} \beta)$ were $<$

$150.50 \mu \mathrm{g} \mathrm{kg}^{-1}$. The mean within-laboratory reproducibility ranged from $5-22 \%\left(\% \mathrm{RSD}_{\mathrm{IR}}\right)$.

16 Endogenous steroids (ex. testosterone, epitestosterone and androstenedione), have been included in

17 the method, to provide insights into the levels of these steroids as findings of these endogenous

18 steroids have been made several times during the period where analysis has been made of imported 19 meat.

\section{Introduction}

24 The use of androgen steroids is forbidden for fattening purposes in the European Community [1].

25 The most suitable matrices for control of abuse is often urine, faeces, plasma and kidney fat, but for 
26 control of abuse of these compounds in import from third countries to the EU, these matrices are not available. Therefore a sensitive and specific method for screening and confirmation of these substances in muscle, has been developed. In 2007 Denmark imported 6300 tons of beef directly consumed in Denmark.

Since the European Commission has set $1 \mu \mathrm{g} \mathrm{kg}^{-1}$ as the recommended concentrations for most steroids in muscle tissue [2] a very sensitive method has to be used and it must be in compliance and validated in accordance with the criteria of the Commission Decision 2002/657/EC [3].

A confirmatory method has been developed for the determination of chlormadinone acetate, megestrol acetate, melengestrol acetate, medroxyprogesterone acetate, methyltestosterone, $\alpha / \beta$ boldenone, methylboldenone, $\alpha / \beta$-trenbolone, $\alpha / \beta$-nortestosterone, altrenogest, testosterone, epitestosterone, androstenedione and clostebolacetate (screening only) in muscle from bovine. The steroids represent both gestagens and androgens and both synthetic and endogenous steroids have been included. The method has the advantages that the amount of organic solvents consumed is very low, no evaporation steps are needed and because of appropriate cleanup and reduced amount of sample material, the matrix effect is low. Since 2007, analysis for steroids in meat from third countries has been included in the Danish residue plan and the developed method is part of the flexible accreditation our laboratory has been assigned by the Danish Accreditation and Metrology Fund - DANAK [4]. As a consequence of the survey on the use of veterinary medicinal products in third countries prepared in 2009 [5], the substances altrenogest and clostebolacetat were included in the method. Clostebolacetate, though, was not included in the accreditation because some criteria regarding confirmation was not fulfilled. 
50 The procedure involves hydrolysis, defattening with heptane, clean up with SPE using C18

51 cartridges and final filtration. Analytes were analysed using liquid chromatography (LC) coupled

52 with tandem mass spectrometry $\left(\mathrm{MS}^{2}\right)$, and quantification was performed using spiked standards in

53 combination with deuterated internal standards. Two ion transitions were monitored for each

54 analyte. The decision limits $(\mathrm{CC} \alpha)$ and detection capabilities $(\mathrm{CC} \beta)$ were well below the

recommended concentration which is set at $1 \mu \mathrm{g} \mathrm{kg}^{-1}$. The mean within-laboratory reproducibility ranged from 5 to $22 \%\left(\% \mathrm{RSD}_{\mathrm{IR}}\right)$. The method is sensitive and reliable and has been used for import 57 control during the last two years. In addition to the detection and quantification by LC-MS/MS, 58 detection by exact mass measurement using time-of-flight mass spectrometry (LC-TOFMS) has 59 been demonstrated. The three endogenous steroids testosterone, epitestosterone and 60 androstenedione, have been included in the method to get knowledge about the levels of these 61 steroids and findings of these steroids have been made several times. A fractional factorial design 62 was used to evaluate the performance of the method when introducing changes in possible critical 63 factors.

\section{Materials and methods}

\section{Materials and reagents}

All reagents were of analytical or HPLC grade and supplied by Merck (Darmstadt, Germany) and Rathburn Chemicals (Walkerburn, Scotland). Water was ultra-purified using a Maxima purification system from USF Elga (Bucks, UK). Protease Type VIII from B. Licheniformis was from Sigma-Aldrich (St. Louis, MO, USA). Medroxyprogesteronacetate (MPA), Megestrolacetate (MGA), Chlormadinonacetate (CMA), Methyltestosterone (MT), $\beta$-Nortestosterone (BNO), Testosterone (TES), epitestosterone (ETE), Androstenedione (ASD), Clostebolacetate (CLAc) and Altrenogest (ALTR) were purchased from Sigma-Aldrich, Melengestrolacetate (MLA) was purchased from Steraloids Inc. (Newport, USA), $\alpha$-Trenbolon (ATR) was bought from LGC 
PromoChem (National Analytical Reference Laboratory, Australia), Methylboldenon (MBO), $\alpha-$

Boldenon (ABO), $\beta$-Boldenon (BBO), $\beta$-Trenbolon (BTR) and $\alpha$-Nortestosteron (ANO),

Medroxyprogesteronacetate- $\mathrm{d}_{3}\left(\right.$ MPA- $\left.\mathrm{d}_{3}\right)$, Megestrolacetate- $\mathrm{d}_{3}\left(\right.$ MGA- $\left.\mathrm{d}_{3}\right)$, Melengestrolacetate- $\mathrm{d}_{3}$

Methylboldenone- $\mathrm{d}_{3}\left(\right.$ MBO- $\left.\mathrm{d}_{3}\right), \beta$-Nortestosteron- $\mathrm{d}_{3}\left(B N O-\mathrm{d}_{3}\right)$ and $\beta$-Trenbolon- $\mathrm{d}_{2}\left(B T R-\mathrm{d}_{2}\right)$ were purchased from RIVM (Bilthoven, The Netherlands). Stock solutions of each compound were prepared separately in ethanol at concentrations of $1 \mathrm{mg} \mathrm{mL}^{-1}$. Stock solutions of internal standards, however, were prepared by reconstitution of ampoules containing a fixed amount of material with ethanol at a concentration of $0.1 \mathrm{mg} \mathrm{mL}^{-1}$. Stock solutions were stored at $-18^{\circ} \mathrm{C}$ until use for up to 3 year. A final working solution containing all the compounds at $0.1 \mu \mathrm{g} \mathrm{mL} L^{-1}$, except internal standards, was prepared by diluting stock solutions with ethanol. A final working solution of internal standards containing all nine internal standards at $0.1 \mu \mathrm{g} \mathrm{mL} \mathrm{L}^{-1}$ was also prepared by diluting stock solutions with ethanol. Final working solutions were freshly made. Samples were cleaned up on C18 SPE-columns (500 mg, $3 \mathrm{~mL}$, Waters Corp. Milford, MA, USA) and filtrated through NH2 SPE columns (500 mg, $5 \mathrm{~mL}$, Waters Corp.).

\section{Samples}

Bovine muscle was either collected at slaughterhouses, as part of the national plan for monitoring drug residues in animals and animal products, or samples were obtained from local supermarkets. As soon as the samples were received, fat and tendons were removed, they were homogenized (appr. $100 \mathrm{~g}$ ) in a blender and stored at $-18{ }^{\circ} \mathrm{C}$ until analysis. Poultry muscle, used for the factorial design, was bought from local supermarkets and treated as bovine muscle.

\section{Sample preparation}

Muscle tissue was homogenised, and $1 \mathrm{~g}$ was transferred to a centrifuge tube. $20 \mu \mathrm{L}$ internal standard working solution $\left(0.1 \mu \mathrm{g} \mathrm{mL}^{-1}\right)$ and $2 \mathrm{~mL}$ of freshly prepared Protease solution $\left(1 \mathrm{mg} \mathrm{mL}^{-1}\right.$ 
98 in Tris buffer, $\mathrm{pH}$ 9.5) was added and the sample was vortexed. The sample was then stored at 50

$99{ }^{\circ} \mathrm{C}$ for two hours (every $30 \mathrm{~min}$. the sample was vortexed for one min.) or 3 hours during factorial 100 experiment. The sample was extracted twice with $2 \mathrm{~mL}$ of methanol. The sample was washed with $3 \mathrm{~mL}$ of heptane and $15 \mathrm{~mL}$ of water was added. The sample was applied to the C18 SPE-column $(500 \mathrm{mg}$ ) pre-activated with $3 \mathrm{~mL}$ of methanol and $3 \mathrm{~mL}$ of water. After washing with $2 \times 2.5 \mathrm{~mL}$ of water, $2 \times 2.5 \mathrm{~mL}$ of acetone/water $(20 / 80 \mathrm{v} / \mathrm{v})$ and $2 \times 2.5 \mathrm{~mL}$ heptane the column was vacuum-dried for $5 \mathrm{~min}$.

The analytes were eluted from the column with $5 \mathrm{~mL}$ of acetonitrile and filtered through a NH2 SPE-column (500 mg) from Waters, pre-activated with $5 \mathrm{~mL}$ of acetonitrile. Further $2 \mathrm{~mL}$ of acetonitrile was filtered through the NH2 SPE-column. The extract (app. $7 \mathrm{~mL}$ ) was dried using a nitrogen evaporator at $40{ }^{\circ} \mathrm{C}$. The residue was reconstituted with $200 \mu \mathrm{L}$ of acetonitrile/water/acetic acid $(35 / 65 / 0.1)$.

\section{$L C-M S / M S$ analysis}

HPLC separation was performed on an Agilent 1100 series LC system from Agilent Technologies (Palo Alto, CA, USA) equipped with a high-pressure binary pump, degasser, auto sampler and a column heater. The steroids were separated on an Atlantis C18 column $(2.1 \mathrm{~mm} * 150 \mathrm{~mm}, 3 \mu \mathrm{m})$ from Waters Corp. at $40{ }^{\circ} \mathrm{C}$ using a gradient method. Mobile phase A contained a mixture of $0.1 \%$ acetic acid in water and acetonitrile $(65: 35, \mathrm{v} / \mathrm{v})$ and mobile phase $\mathrm{B}$ contained acetonitrile, and the flow rate was set at $0.2 \mathrm{~mL} \mathrm{~min}^{-1}$. The sample volume injected was $50 \mu \mathrm{L}$.

The mass spectrometer used was a Quattro Ultima Pt triple quadropole instrument (Waters Corp.) with Masslynx v. 4.0 software (Waters Corp.). Ionisation of the analytes was achieved using an electrospray interface in the positive ion mode $\left(\mathrm{ESI}^{+}\right)$, and ionisation source parameters were as follows: capillary voltage $\left(\mathrm{V}_{\text {cap }}\right), 3.5 \mathrm{kV}$; cone voltage $\left(\mathrm{V}_{\text {cone }}\right), 40 \mathrm{~V}$; RF Lens 1 voltage $\left(\mathrm{V}_{\text {Ref1 }}\right), 15$ 
$\mathrm{V}$; desolvation temperature, $400^{\circ} \mathrm{C}$; source temperature, $120^{\circ} \mathrm{C}$. Nitrogen was used as the nebulising gas (maximum flow), desolvation gas (flow-rate of $600 \mathrm{~L} \mathrm{~h}^{-1}$ ), and the cone gas (flow-rate of $120 \mathrm{~L}$

$\mathrm{h}^{-1}$ ). Argon was used as the collision gas at a pressure of $\sim 2.2 \times 10^{-3}$ mbar. Data acquisition was performed in the multiple reaction monitoring (MRM) mode. MRM transitions and collision energies for the analytes are listed in Table 1, and the dwell time was set to $0.2-0.3 \mathrm{~s}$ for trenbolon and $0.1 \mathrm{~s}$ for other transitions.

Spiked standards were used to quantify the analytes. The fortification levels of the validation curves were: 0.0 (blank sample), $0.125,0.25,0.5,1.0,2.04 .0,8.0 \mu \mathrm{g} \mathrm{kg}^{-1}$, and a fixed amount of internal standard $\left(0.5,2.0\right.$ or $4.0 \mu \mathrm{g} \mathrm{kg}^{-1}$ depending on the steroid) was added to all the samples. Calibration curves were obtained by plotting response of the analyte versus nominal concentrations $\left(\mathrm{ng} \mathrm{mL} L^{-1}\right)$ added of the analyte and response is defined as the chromatographic peak area of the analyte divided by the area of the related internal standard, multiplied with concentration of internal standard. Deuterated labelled standards are suitable for quantification purposes and if a deuterated standard was not available for a steroid a deuterated epimer standard was used or a deuterated standard with a matching retention time was used. Therefore MLA- $\mathrm{d}_{3}$ was used as an internal standard for CMA and CLAc, BBO- $\mathrm{d}_{3}$ was used as an internal standard for ABO (epimer), BTR- $\mathrm{d}_{2}$ was used as an internal standard for ATR (epimer), BNO- $\mathrm{d}_{3}$ was used as an internal standard for ANO (epimer) and MT- $\mathrm{d}_{3}$ was used as an internal standard for ASD, ALTR and ETE.

UHPLC-TOFMS analysis

UHPLC was performed on a Waters Acquity UHPLC system (Waters Corp.) equipped with a high-pressure binary pump, degasser, autosampler and a column heater.

The steroids were separated on an Acquity UPLC BEH C18 column $(2.1 \mathrm{~mm} * 50 \mathrm{~mm}, 1.7 \mu \mathrm{m})$ from Waters at $40{ }^{\circ} \mathrm{C}$ using isocratic conditions. Mobile phase contained a mixture of $0.1 \%$ acetic acid 
in water and methanol $(35: 65, \mathrm{v} / \mathrm{v})$, and the flow rate was set at $0.25 \mathrm{~mL} \mathrm{~min}^{-1}$. The sample volume injected was $5 \mu \mathrm{L}$.

The mass spectrometer used was an LCT Premier ${ }^{\mathrm{TM}} / \mathrm{XE}$ time-of-flight mass spectrometer (Waters Corp.) with Masslynx v. 4.1 software (Waters Corp.). Ionisation of the analytes was achieved using an electrospray interface in the positive ion mode $\left(\mathrm{ESI}^{+}\right)$and ionisation source parameters were as follows: capillary voltage, $3.0 \mathrm{kV}$; desolvation temperature, $350^{\circ} \mathrm{C}$; source temperature, $120^{\circ} \mathrm{C}$; cone voltage, $30 \mathrm{~V}$; desolvation gas (flow-rate of $700 \mathrm{~L} \mathrm{~h}^{-1}$ ), and the cone gas (flow-rate of $10 \mathrm{~L} \mathrm{~h}^{-1}$ ). Data were collected in $\mathrm{W}$-optics centroid mode over a mass range of 70$1000 \mathrm{Da}$ with a scan time of $0.1 \mathrm{~s}$. For the dynamic range enhancement (DRE) lockmass, a solution of leucine-enkephalin at $50 \mu \mathrm{g} \mathrm{L}{ }^{-1}$ was infused through an infusion pump at $10 \mu \mathrm{L} \mathrm{min}^{-1}$.

\section{Results and discussion}

\section{Method development}

The method developed by Blasco et al [6] was selected as the starting point for method development. It was decided not to include a hydrolysis step as less than $20 \%$ of testosterone and less than $5 \%$ of $\beta$-oestradiol was in the conjugated form in muscle tissue [7-9]. The tissue was initially enzymatically degraded by Protease Type VIII, leading to a homogenious suspension. The MS/MS fragmentation observed for the steroids was similar to that reported in earlier studies [6, 1014]. Precursor and daughter ions selected for LC-MS/MS quantification and confirmation are shown in Table 1. Due to the natural isotopic abundances of carbon and hydrogen, certain MRM transitions produce a signal for both MPA and MGA. Use of $65 \%$ methanol as mobile phase and a Symmetry LC-column, under isocratic conditions, was presented by S. Mortensen et al [15] for separating these transitions. We have used acetonitrile under gradient conditions to achieve full separation of MGA and MPA. Likewise the close eluting isomers of trenbolon ( $\alpha$ - and $\beta$-trenbolon) 
168 were separated using the same gradient. Ion suppression due to matrix effect can be a serious problem when using ESI ionization [16] and is primarily caused by the presence of endogenous

substances [17- 18]. Ion suppression was investigated during method development and it was found to be less than $20 \%$ for most steroids and less than $35 \%$ for the gestagens. It was shown that increasing the amount of sample (and solvents used for cleanup), resulted in more ion suppression. It was therefore decided to use only $1 \mathrm{~g}$ of tissue sample to reduce ion suppression. When using $1 \mathrm{~g}$ of sample it was likewise possible to decrease the amount of organic solvents. Often dilution of the sample or injecting less volume is used for reducing matrix effect, but this would in this study also increase the detection limit which is not desirable.

\section{Method validation}

The method was initially validated for the determination of 15 androgens in bovine muscle tissue according to Commission Decision 2002/657/EC [3] to be used for control of muscle tissue imported to the domestic market. Later altrenogest and clostebolacetate were included. Analytes were quantified using spiked standards, i.e. muscle samples spiked with analytes and deuterated internal standards prior to sample preparation. For the endogenous steroids (testosterone, epitestosterone and androstenedione) external calibration curve was used. The calibration standards were measured before and after the test samples and determination coefficients $\left(\mathrm{R}^{2}\right)$ were larger than 0.95 for all analytes. For the determination of specificity 20 different blank muscle samples were analysed. No interferences were observed in the region of the retention times for any of the steroids except melengestrolacetate where interferences occurred in some samples $\left(<0.2 \mu \mathrm{g} \mathrm{kg}^{-1}\right)$ and since the ion ratio was more than 10 times higher than the target value it was concluded that it was not due to carry over or possible treatment of the animal but "noise". MRM chromatograms of a blank muscle sample fortified with all analytes are shown in figure 1. 
Precision (repeatability and intra-laboratory reproducibility) and trueness were determined by spiking blank muscle tissue samples with the steroids at four concentration levels. Repeatability and intra-laboratory reproducibility are expressed as relative standard deviations $\left(\% \mathrm{RSD}_{\mathrm{r}}\right.$ and $\left.\% \mathrm{RSD}_{\mathrm{IR}}\right)$ in Table 2. For a few steroids the precision was slightly less at the lowest spike level than for the other three concentration levels. Precision and trueness for the endogenous steroids were calculated by subtracting the quantitative result of unspiked samples from the result of spiked sample probably leading to a slight overestimation of the precision.

Since no certified reference material was available, en estimate of trueness was determined by calculating the recovery (corrected with internal standard) of fortified blank samples. Trueness was determined by analysing 78 spiked samples and ranged from $97-107 \%$. In our laboratory, matrix effect, is now a mandatory parameter to calculate when developing and validating a method, based on ESI detection. In order to calculate matrix effect, samples of muscle tissue were extracted and the final extracts were spiked at $1 \mu \mathrm{g} / \mathrm{kg}$ and analysed. A standard solution in solvent with the 5 $\mu \mathrm{g} / \mathrm{L}$ was likewise prepared and analysed. Matrix effect, or ion suppression, is calculated as the relative difference between the area of the standard solution and the extracted sample. Matrix effect was less than $20 \%$ except for the acetylgestagens where matrix effect was $20-34 \%$, and it was decided not to try to reduce matrix effect further.

Decision limit (CC $\alpha)$ means the limit at and above which it can be concluded with an error probability of $\alpha$ that a sample is non-compliant [3]. CC $\alpha$ values were estimated from the noise level for the primary and secondary transition as well as from the standard deviation on uspiked samples or samples spiked at low level. Final results are presented in Table 3. Detection capability (CC $\beta$ ) means the smallest amount of analyte that may be detected, identified and quantified in a sample with an error probability of $\beta$. For banned substances with no permitted limit, the detection capability is the lowest concentration at which the method is able to detect truly contaminated 
samples with a statistical certainty of $1-\beta . \operatorname{CC} \beta$ was calculated as the value of the decision limit plus 1.64 times the intra-laboratory standard deviation $\left(S_{R}\right)$ of the measured concentrations in samples spiked at a level close to the CC $\beta$ [3]. For the analytes, where the calculated CC $\beta$ is below the spiking level, $C C \beta$ is given as the spike level in Table 3. For practical reasons the decision limit for the endogenous steroids is estimated by analysis of samples where a quantitative result, and a $\mathrm{S} / \mathrm{N}$ ratio, is given at low level. The $\mathrm{S} / \mathrm{N}$ ratio and the quantitative result, for these steroids, is used for estimating the $\mathrm{CC} \alpha$.

According to Commission Decision 2002/657/EC, an analyte is identified by assessing the retention time and the abundance of specific ions. When using LC-MS/MS in the MRM mode for confirmation, two transition ions have to be detected, both with a signal-to-noise ratio $>3$. In addition, the maximum permitted tolerances for relative ion intensities also have to be fulfilled. Results from the determination of precision are used for calculating ion ratio. For 13 analytes (out of 17) the criteria on ion ratio was fulfilled in the concentration range $0.5-2.0 \mu \mathrm{g} \mathrm{kg}^{-1}$ when only one injection is made. The results are presented in table 4.

In addition it is possible to confirm the mass of the substance with accurate mass spectrometry. As can be seen in figure 2 the compound eluting at retention time $8.35 \mathrm{~min}$. is identified by the retention time and the two transitions when using LC-MSMS and by using LC-TOFMS identification is supported by correct mass detection. In figure 3 the mass of $\alpha$-nortestosterone (RT $=4.39 \mathrm{~min}$.) is measured with less than $5 \mathrm{ppm}$ precision in a sample with $10 \mathrm{ppb}$ and the signal to noise ratio is 50 for the extracted TOFMS chromatogram.

\section{Factorial effect experiment}

During method development a factorial experiment was done to evaluate the performance of the method, when introducing changes in possible critical factors. When running the method on a routine basis, it is likewise practical to know whether treatment of the meat sample before analysis 
can influence the analytical result (ex. freeze-thaw cycles). Five factors were evaluated: a) amount of sample $(0.5 \mathrm{~g}$ or $1.0 \mathrm{~g})$; b) species (bovine or poultry); c) temperature during cleanup/centrifugation $\left(4{ }^{\circ} \mathrm{C}\right.$ or $20{ }^{\circ} \mathrm{C}$ ); d) freeze-thaw cycles of sample before analysis (once or twice); e) duration of hydrolysis (two hours or three hours), and a factorial design was used for estimating the factors. For practical purposes a $1 / 4 \times 2^{5}$ fractional design was used and to evaluate the influence of the factors each factor setup was done in replicate. The number of samples was hereby reduced from 64 samples to 16 samples and the statistical evaluation was done in accordance with Miller and Miller [19] using an F-test for testing the factors. In figure 4 each diagram represent one factor (the factor "time of incubation for hydrolysis" is not shown since no effect was observed when changing this factor). The relative difference between the two levels is shown and on the left side in the diagram, the response is used for calculation and on the right side the area is used for calculating the difference. For clostebolacetate it can be seen that the relative difference between the two levels is exceeding $10 \%$ for two factors, "species" and "sample amount" (using response and area), but since the precision for this compound is large and not accepted for confirmation this steroid will not be used for testing the factors. It was demonstrated that none of the factors had an effect on the analytical performance when testing the responses (taking internal standard into account) for most steroids. When testing the areas, the factors "species" and "amount of sample" had an effect on the analytical performance but the other factors had no significant effect. The factor "species" included bovine and poultry and it was shown that the absolute recovery was higher when testing bovine compared to poultry. Likewise the absolute recovery was higher when using $1 / 2 \mathrm{~g}$ of meat sample compared to $1 \mathrm{~g}$.

Real sample analysis

The developed method has been used for the past two years, primarily, for import control. 
Nearly 100 samples of beef have been analysed and in many samples endogenous steroids have

\section{Conclusion}

been found. In $22 \%, 72 \%$ and $54 \%$ of the samples testosterone ( $\max .0 .6 \mu \mathrm{g} \mathrm{kg}^{-1}$ ), epitestosterone

(max. $1.6 \mu \mathrm{g} \mathrm{kg}^{-1}$ ) and androstenedione (max. $2.8 \mu \mathrm{g} \mathrm{kg}^{-1}$ ) were found. The findings of testosterone, epitestosterone and androstenedione are in line with already published data [20-22]. In eight samples, both testosterone and the epimer was found with a testosterone/epitestosterone (T/E) ratio of 0.1 - 3.2. In human sport, misuse of testosterone has been detected by measurement of the T/E ratio in urine [23]. A T/E-ratio in urine exceeding 6 indicated misuse of testosterone. Since the interconversion of testosterone and androstenedione to epitestosteron is species specific the same T/E ratio cannot be used, according to Angeletti and coworkers [21] and their results found that a difference of T/E-ratio in urine from treated and untreated calves could not immediately be done.

A method has been presented for confirmation of steroids in muscle tissue. The method is fully validated and the intra-laboratory reproducibility is acceptable for all substances and the CC $\alpha$ and $\mathrm{CC} \beta$ is below $1 \mu \mathrm{g} \mathrm{kg}^{-1}$ which is the recommended concentration set by the European Commission. The MRM transition ratios are fulfilling the criterias for confirmation and the consumption of solvents is low due to the small sample size $(1 \mathrm{~g})$ and use of LC-TOF is possible for confirming the mass of the substance. Inclusion of new substances, because of new information, is presented, and a fractional factorial design is shown to be useful during method development and method validation. The described procedure was successfully used in the residue control and the findings of endogenous steroids are in line with already published data.

\section{Acknowledgements}

We thank Lis Abildgaard Andersen, Maud Bering Andersen and Lene Gram Hansen for their skilful technical assistance with the chemical analyses. 


\section{References}

[1] Council Directive 96/22/EC. Off. J. Eur. Commun. L 125 (1996) 3.

[2] Community Reference Laboratories for Residues (2007): CRL guidance paper, December 2007: CRLs view on the state of the art analytical methods for national residue plans.

[3] Commission Decision 2002/657/EC. Off. J. Eur. Commun. L 221 (2001) 8.

[4] Database on accreditated methods in the National Food Institute (http://published.danak.dk/register.asp?nohead=y\&lang=d\&akk=350)

[5] Sharmann M., Thomas M. Scientific/Technical Report submitted to EFSA. CFP/EFSA/CONTAM/2008/02. Published on 10 December 2009.

[6] Blasco C. et al. Analysis of meat samples for anabolic steroids residues by liquid chromatography/tandem mass spectrometry. J. Chrom. A 1154 (2007) 230-239.

[7] Hartmann S., Steinhart H. Simultaneous determination of anabolic and catabolic steroid hormones in meat by gas-chromatography-mass spectrometry. J. Chrom. B 707 (1997) 105- 117.

[8] Maume D. et al. Modification of 17 $\square$-estradiol metabolite profile in steer edible tissues after estradiol implant administration.. Anal. Chim. Acta 483 (2003) 289-297.

[9] Marchand P. et al. Ultra trace detection of a wide range of anabolic steroids in meat by gas chromatography coupled to mass spectrometry. J. Chrom. A 867 (2000) 219-233.

[10] Schmidt KS. et al. In-house validation and factorial effect analysis of a liquid chromatography-tandem mass spectrometry method for the determination of steroids in bovine muscle. Anal. Chim. Acta 637 (2009) 156-164.

[11] Malone EM. et al. Development of a rapid method for the analysis of synthetic growth promoters in bovine muscle using liquid chromatography tandem mass spectrometry. Anal. Chim. Acta 637 (2009) 112-120.

[12] Shao B. et al. Simultaneous determination of residual hormonal chemicals in meat, kidney, liver tissues and milk by liquid chromatography-tandem mass spectrometry. Anal. Chim. Acta 548 (2005) 41-50.

[13] Kaklamanos G. et al. Determination of anabolic steroids in muscle tissue by liquid chromatography-tandem mass spectrometry. J. Chrom. A 1216 (2009) 8072-8079.

[14] Van Poucke C. Determination of anabolic steroids in dietary supplements by liquid chromatography-tandem mass spectrometry. Anal. Chim. Acta 586 (2007) 35-42. 
[15] Mortensen S., Pedersen M. Confirmatory analysis of acetylgestagens in plasma using liquid

6317 chromatography- tandem mass spectrometry. Anal. Chim. Acta 586 (2007) 217-222.

8318 [16] Andersen JH. et al. Optimization of soild phase extraction clean up and validation of quantitative determination of corticosteroids in urine by liquid chromatography-tandem mass spectrometry. Anal. Chim. Acta 617 (2008) 216-224.

[17] H. Mei, Matrix effects: causes and solutions, in: W.A. Korfmacher (Ed.), Using Mass Spectrometry for Drug Metabolism Studies, CRC Press, 2004, ISBN 0849319633.

[18] J.-P. Antignac, K. De Wasch, F. Monteau, H. De Brabander, F. Andre, B. Le Bizec. Anal. Chim. Acta 529 (2005) 129-136.

[19] J. N. Miller, J. C. Miller. Statistics and chemometrics for analytical chemistry. 4 ed. (2000), Prentice Hall.

[20] Gaiani R., Chiesa F. Physiological levels of androstenedione and testosterone in some edible tissues from calves, bulls and heifers . Meat Sci. 17 (1986) 177-185.

[21] Angeletti R. et al. The urinary ratio of testosterone to epitestosterone: a good marker of illegal treatment also in cattle?. Vet. Res. Comm. 30(Suppl. 1) (2006) 127-131.

[22] Hartmann S. et al. Natural occurence of steroid hormones in food. Food Chem. 62 (1) (1998) $7-20$.

[23] Linnet K. Effect of the biological matrix on the urinary testosterone/epitestosterone ratio measured by gas chromatography/mass spectrometry in doping analysis. Biol. Mass Spectr. 22 (1993) 412-418. 
Figure captions:

Figure 1. Bovine muscle fortified with all analytes at a concentration of $1 \mu \mathrm{gg}^{-1}$.

Figure 2. LC-MS/MS of bovine muscle fortified with all analytes at a concentration of $10 \mu \mathrm{g} \mathrm{kg}^{-1}$. (a) Total ion chromatogram. (b) Extracted ion chromatogram corresponding to $\alpha$-nortestosteron $(\mathrm{RT}=8.35)$.

Figure 3. LC-TOFMS of bovine muscle fortified with $\alpha$ - and $\beta$-nortestosteron at a concentration of $10 \mu \mathrm{g} \mathrm{kg}^{-1}$. (a) Extracted ion chromatogram. (b) Scan of $\alpha$-nortestosteron (down) and isotopic spectrum corresponding to $\alpha$-nortestosteron (upper)

Figure 4. Graphical presentation of four factors "species" (a), "sample amount" (b), "temperature during sample cleanup" (c) and "treatment of sample before analysis" (d). 


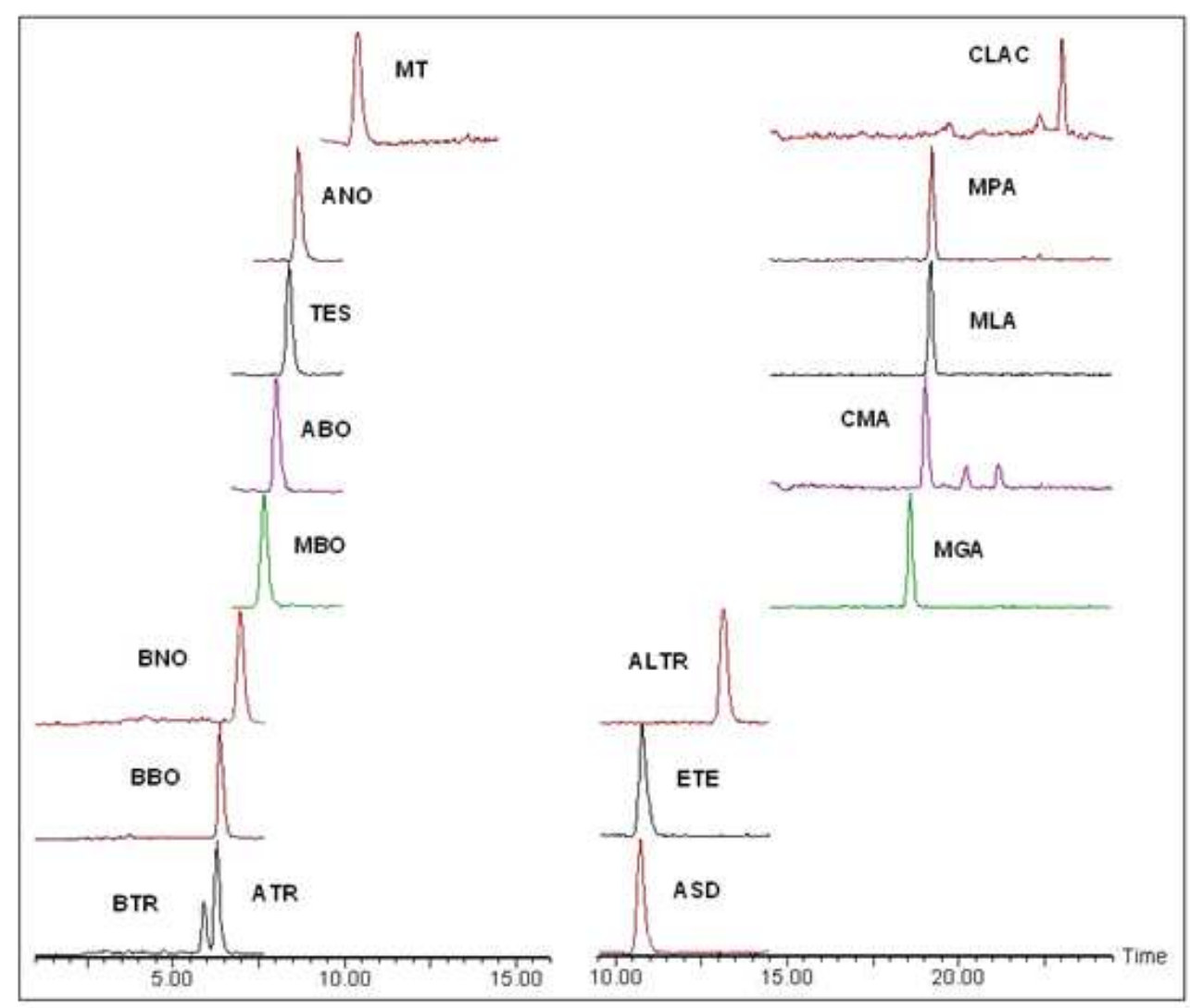

$147 \times 125 \mathrm{~mm}(96 \times 96 \mathrm{DPI})$ 


1
1
3
4
5
6
7
8
9
10
11
12
13
14
15
16
17
18
19
20
21
22
23
24
25
26
27
28
29
30
31
32
33
34
35
36
37
38
39
40
41
42
43
44
55
50
56
57
48
59
50
51
53
50

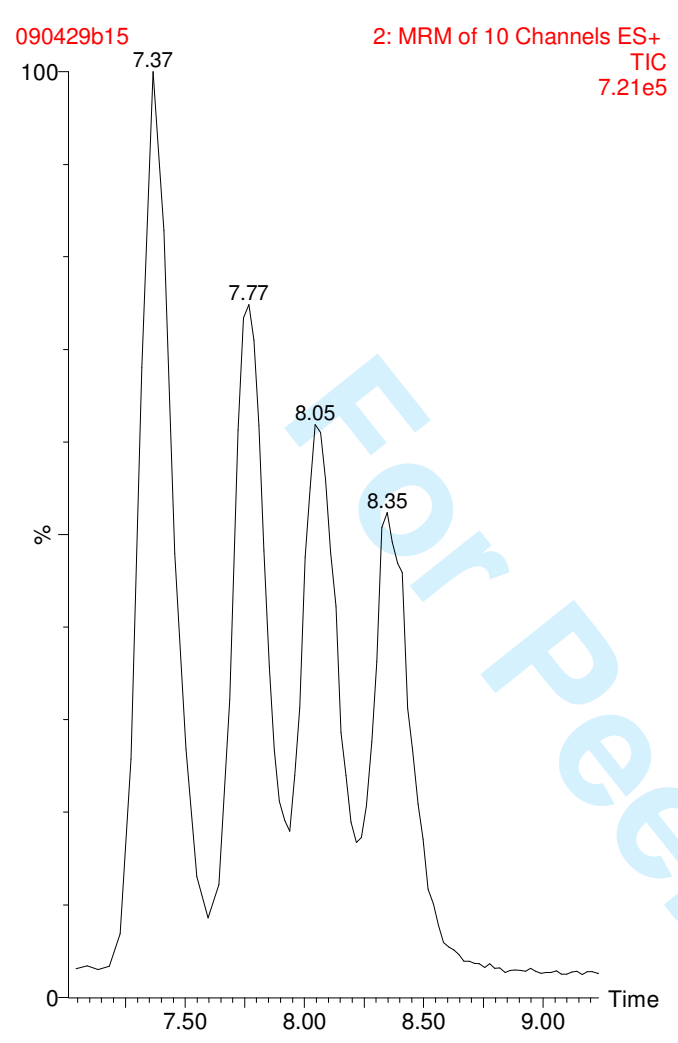

(a)

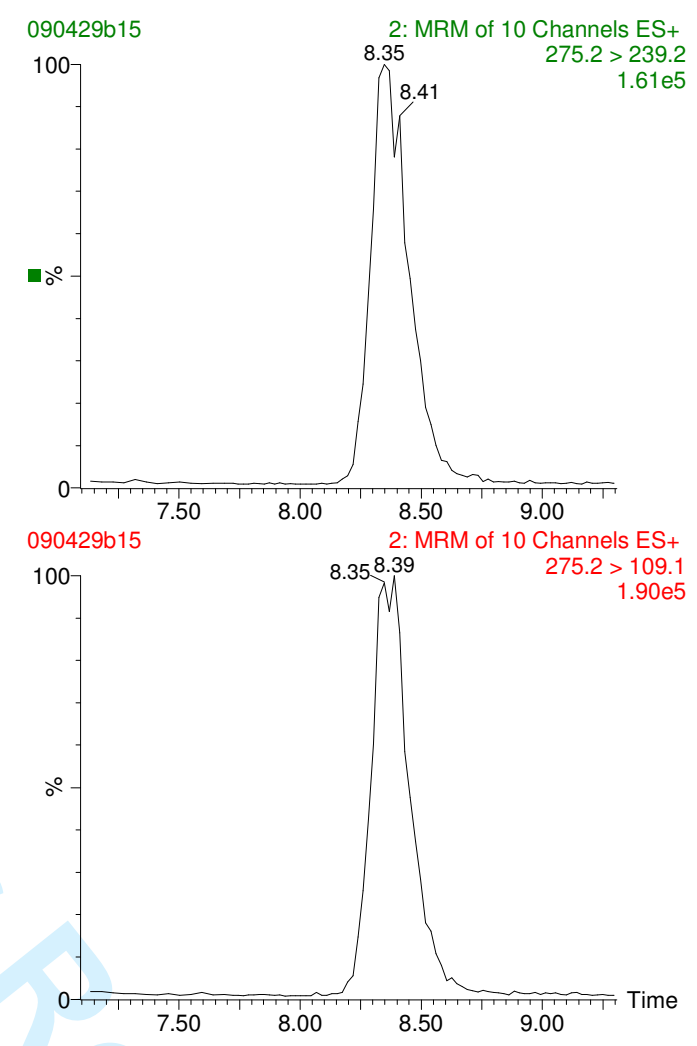

(b) 


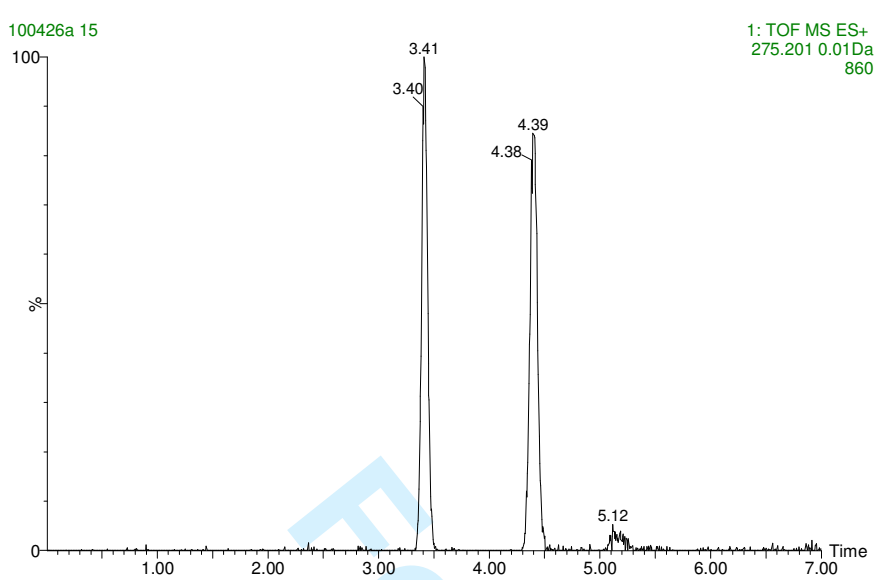

(a)

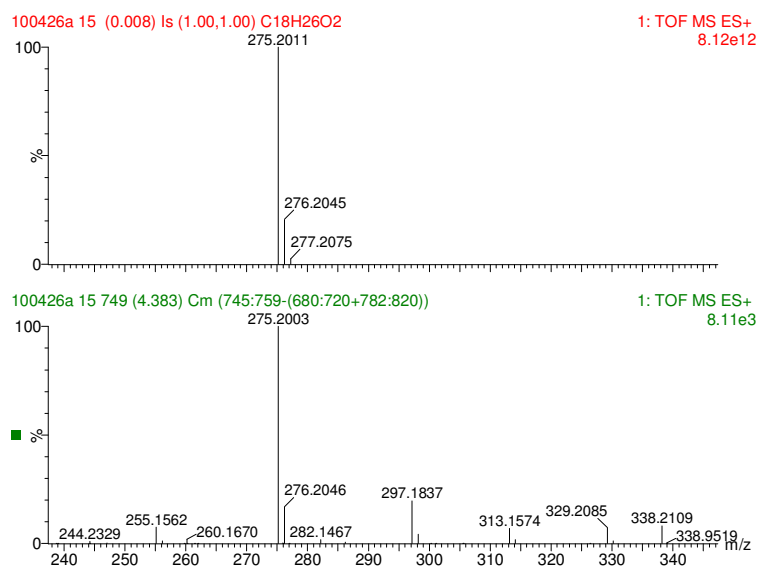

(b)

17

18

19

20

21

22

23

24

25

26

27

28

29

30

31

32

33

34

35

36

37

38

39

40

41

42

43

44

45

46

47

48

49

50

51

52

53

54

55

56

57

58

59

60

http://mc.manuscriptcentral.com/tfac Email: fac@tandf.co.uk 

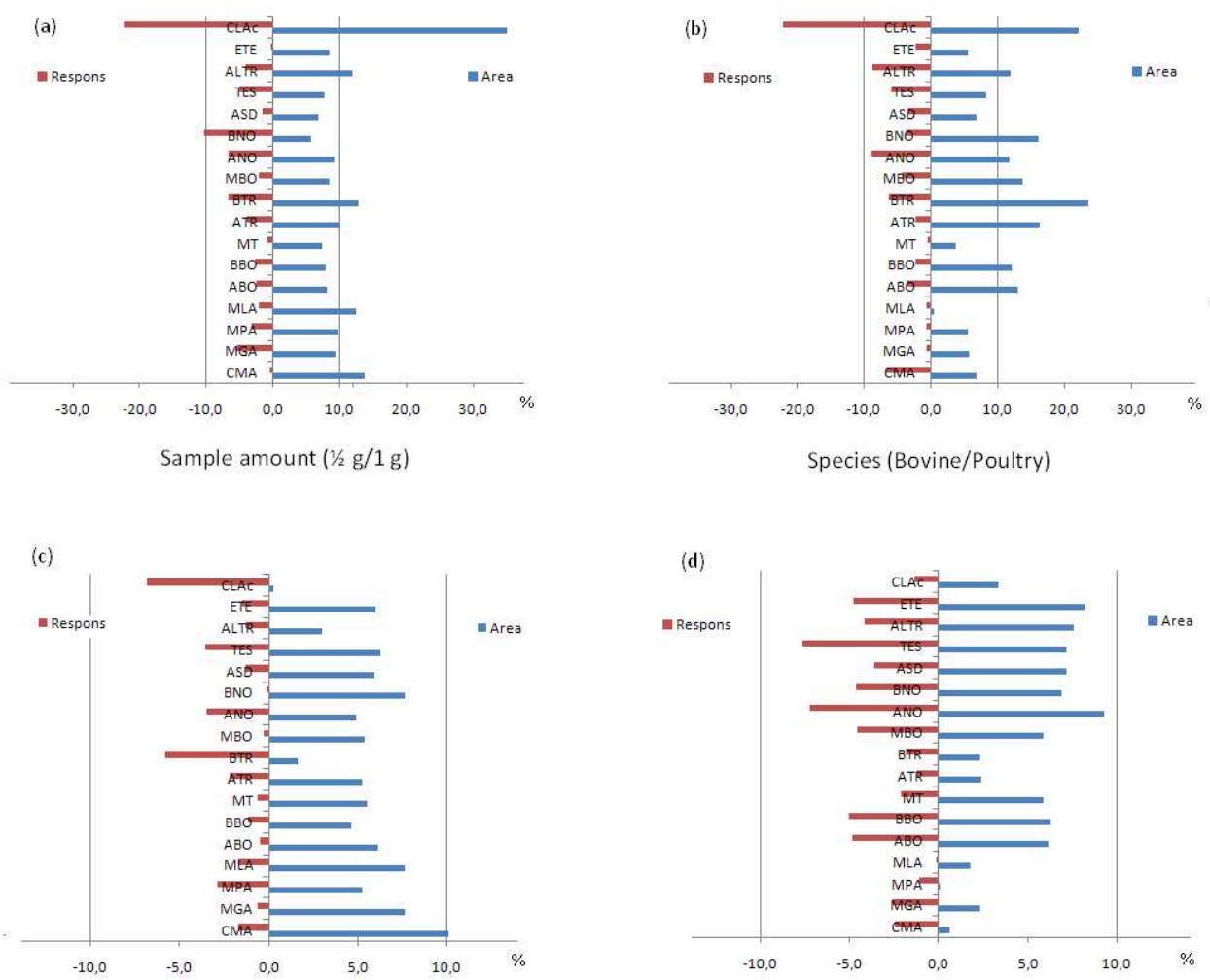

Temperature when centrifugation $\left(4^{\circ} \mathrm{C} / 20^{\circ} \mathrm{C}\right)$

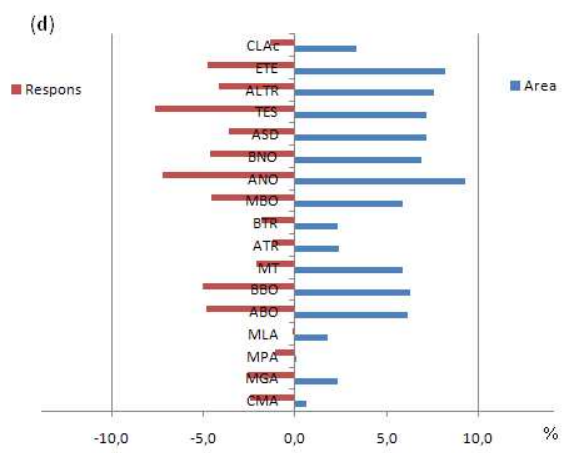

Treatment of sample (freeze/thaw/freeze/thaw)

$275 \times 234 \mathrm{~mm}(96 \times 96$ DPI) 
Table 1. Data acquisition method for analysis by LC-MS/MS.

\begin{tabular}{|c|c|c|c|}
\hline Name (abbreviation) & $\mathrm{R}_{\mathrm{t}}$ (min.) & MRM transitions $(m / z)^{\mathrm{a}}$ & Collision energy $(\mathrm{eV})$ \\
\hline \multirow[t]{2}{*}{ Medroxyprogesterone acetate (MPA) } & 19.1 & $387.3>327.2$ & 14 \\
\hline & & $(387.3>285.1)$ & 18 \\
\hline \multirow[t]{2}{*}{ Megestrol acetate (MGA) } & 18.4 & $385.3>325.2$ & 12 \\
\hline & & $(385.3>267.1)$ & 18 \\
\hline \multirow[t]{2}{*}{ Chlormadinone acetate (CMA) } & 18.8 & $405.2>309.1$ & 14 \\
\hline & & $(405.2>345.1)$ & 12 \\
\hline \multirow[t]{2}{*}{ Melengestrol acetate (MLA) } & 19.0 & $397.2>337.1$ & 14 \\
\hline & & $(397.2>279.1)$ & 18 \\
\hline \multirow[t]{2}{*}{ Testosterone/epi-Testosterone (TES/ETE) } & $8.4 / 10.7$ & $289.1>97.1$ & 18 \\
\hline & & $(289.1>109.1)$ & 20 \\
\hline \multirow[t]{2}{*}{$\alpha$-Boldenone $/ \beta$-Boldenone $(\mathrm{ABO} / \mathrm{BBO})$} & 7.8/6.4 & $287.2>121.1$ & 18 \\
\hline & & $(287.2>135.1)$ & 15 \\
\hline \multirow[t]{2}{*}{ Methylboldenone (MBO) } & 7.7 & $301.2>149.1$ & 15 \\
\hline & & $(301.2>121.1)$ & 20 \\
\hline \multirow[t]{2}{*}{ Methyltestosterone (MT) } & 10.4 & $303.2>97.0$ & 25 \\
\hline & & $(303.2>109.1)$ & 30 \\
\hline \multirow[t]{2}{*}{$\alpha$-Trenbolon/ $\beta$-Trenbolon (ATR/BTR) } & $6.3 / 5.9$ & $271.2>199.1$ & 20 \\
\hline & & $(271.2>253.2)$ & 20 \\
\hline \multirow[t]{2}{*}{$\alpha$-Nortestosterone $/ \beta$-Nortestosterone (ANO/BNO) } & $8.7 / 7.0$ & $275.2>109.1$ & 22 \\
\hline & & $(275.2>239.2)$ & 17 \\
\hline \multirow[t]{2}{*}{ Androstenedione (ASD) } & 10.3 & $287.0>97.0$ & 20 \\
\hline & & $(287.0>109.0)$ & 20 \\
\hline \multirow[t]{2}{*}{ Altrenogest (ALTR) } & 13.0 & $311.1>227.0$ & 23 \\
\hline & & $(311.1>269.0)$ & 15 \\
\hline \multirow[t]{2}{*}{ Clostebolacetat (CLAc) } & 22.9 & $365.1>142.9$ & 22 \\
\hline & & $(365.1>305.1)$ & 15 \\
\hline Medroxyprogesterone acetate- $\mathrm{d}_{3}\left(\right.$ MPA- $\left.\mathrm{d}_{3}\right)$ & 19.1 & $390.3>330.2$ & 14 \\
\hline Megestrol acetate- $\mathrm{d}_{3}\left(\right.$ MGA- $\left.\mathrm{d}_{3}\right)$ & 18.4 & $388.4>270.2$ & 18 \\
\hline Melengestrol acetate- $\mathrm{d}_{3}\left(\right.$ MLA- $\left.\mathrm{d}_{3}\right)$ & 19.0 & $400.1>340.2$ & 14 \\
\hline Methyltestosterone- $\mathrm{d}_{2}\left(\mathrm{MT}-\mathrm{d}_{2}\right)$ & 10.4 & $306.2>97.0$ & 25 \\
\hline Testosterone- $\mathrm{d}_{2}\left(\right.$ TES- $\left.\mathrm{d}_{2}\right)$ & 8.4 & $291.1>99.1$ & 18 \\
\hline$\beta$-Boldenone- $\mathrm{d}_{3}\left(\mathrm{BBO}-\mathrm{d}_{3}\right)$ & 6.4 & $290.2>121.1$ & 15 \\
\hline$\beta$-Nortestosterone- $\mathrm{d}_{3}\left(\mathrm{BNO}-\mathrm{d}_{3}\right)$ & 7.0 & $278.2>109.1$ & 22 \\
\hline Methylboldenone- $\mathrm{d}_{3}\left(\mathrm{MBO}-\mathrm{d}_{3}\right)$ & 7.7 & $304.2>152.0$ & 12 \\
\hline$\beta$-Trenbolon- $\mathrm{d}_{2}\left(\mathrm{BTR}-\mathrm{d}_{2}\right)$ & 5.9 & $273.2>199.1$ & 20 \\
\hline
\end{tabular}

${ }^{a}$ Primary MRM transitions used for quantitative purposes are listed first, and secondary MRM transitions for confirmation are in parentheses. 
Table 2. Repeatability, intra-laboratory reproducibility and corrected recovery in spiked samples of muscle tissue.

\begin{tabular}{|c|c|c|c|c|c|}
\hline Compound & $\begin{array}{c}\text { Nominal } \\
\text { concentration } \\
\left(\mu \mathrm{g} \mathrm{kg}^{-1}\right)\end{array}$ & $\begin{array}{c}\text { Repeatability } \\
\left(\% \mathrm{RSD}_{\mathrm{r}}\right)\end{array}$ & $\begin{array}{l}\text { Intra-laboratory } \\
\text { Reproducibility } \\
\quad\left(\% \mathrm{RSD}_{\mathrm{IR}}\right)\end{array}$ & $\mathrm{N}$ & $\begin{array}{c}\text { Corrected } \\
\text { recovery }(\%)\end{array}$ \\
\hline Medroxyprogesterone acetate & $0.13-1.0$ & 5 & 7 & 78 & 99 \\
\hline \multirow[t]{2}{*}{ Megestrol acetate } & 0.13 & \multirow{2}{*}{6} & 13 & 16 & \multirow{2}{*}{101} \\
\hline & $0.25-1.0$ & & 7 & 62 & \\
\hline \multirow[t]{2}{*}{ Chlormadinone acetate } & 0.13 & \multirow[t]{2}{*}{5} & 12 & 16 & \multirow{2}{*}{100} \\
\hline & $0.25-1.0$ & & 7 & 62 & \\
\hline \multirow[t]{2}{*}{ Melengestrol acetate } & 0.13 & \multirow{2}{*}{5} & 43 & 16 & \multirow{2}{*}{105} \\
\hline & $0.25-1.0$ & & 7 & 62 & \\
\hline \multirow[t]{2}{*}{ Testosterone } & 0.13 & \multirow{2}{*}{10} & 19 & 16 & \multirow{2}{*}{107} \\
\hline & $0.25-1.0$ & & 8 & 62 & \\
\hline epi-Testosterone & $0.25-2.0$ & 4 & 16 & 78 & 103 \\
\hline \multirow[t]{2}{*}{$\alpha$-Boldenone } & 0.13 & \multirow{2}{*}{5} & 12 & 16 & \multirow{2}{*}{98} \\
\hline & $0.25-1.0$ & & 5 & 62 & \\
\hline$\beta$-Boldenone & $0.13-1.0$ & 4 & 7 & 78 & 98 \\
\hline Methylboldenone & $0.13-1.0$ & 4 & 5 & 78 & 101 \\
\hline Methyltestosterone & $0.13-1.0$ & 8 & 9 & 78 & 99 \\
\hline$\alpha$-Trenbolon & $0.25-2.0$ & 15 & 22 & 78 & 98 \\
\hline$\beta$-Trenbolon & $0.5-4.0$ & 8 & 18 & 78 & 98 \\
\hline$\alpha$-Nortestosterone & $0.25-2.0$ & 5 & 8 & 78 & 101 \\
\hline$\beta$-Nortestosterone & $0.25-2.0$ & 7 & 8 & 78 & 107 \\
\hline Androstenedione & $0.25-2.0$ & 6 & 18 & 78 & 107 \\
\hline Altrenogest & $0.5-1.0$ & 9 & 20 & 28 & 98 \\
\hline Clostebolacetat & $0.5-1.0$ & 38 & 49 & 25 & 86 \\
\hline
\end{tabular}


Table 3. $\mathrm{CC}_{\alpha}$ and $\mathrm{CC}_{\beta}$ obtained in muscle tissue.

\begin{tabular}{|c|c|c|}
\hline Compound & $\begin{array}{c}\mathrm{CC} \alpha \\
\left(\mu \mathrm{kg}^{-1}\right)\end{array}$ & $\begin{array}{c}\mathrm{CC} \beta \\
\left(\mu \mathrm{g} \mathrm{kg}^{-1}\right)\end{array}$ \\
\hline Medroxyprogesterone acetate & 0.04 & 0.13 \\
\hline Megestrol acetate & 0.03 & 0.13 \\
\hline Chlormadinone acetate & 0.10 & 0.13 \\
\hline Melengestrol acetate & 0.19 & 0.20 \\
\hline Testosterone & 0.07 & 0.13 \\
\hline epi-Testosterone & 0.08 & 0.25 \\
\hline$\alpha$-Boldenone & 0.02 & 0.13 \\
\hline$\beta$-Boldenone & 0.04 & 0.13 \\
\hline Methylboldenone & 0.02 & 0.13 \\
\hline Methyltestosterone & 0.07 & 0.13 \\
\hline$\alpha$-Trenbolon & 0.16 & 0.33 \\
\hline$\beta$-Trenbolon & 0.33 & 0.50 \\
\hline$\alpha$-Nortestosterone & 0.09 & 0.25 \\
\hline$\beta$-Nortestosterone & 0.10 & 0.25 \\
\hline Androstenedione & 0.12 & 0.25 \\
\hline Altrenogest & 0.06 & 0.50 \\
\hline Clostebolacetate & 0.30 & 0.50 \\
\hline
\end{tabular}


Table 4. Ion ratio data $\left(0.5-2.0 \mu \mathrm{g} \mathrm{kg}^{-1}\right)$.

\begin{tabular}{|c|c|c|c|}
\hline Compound & $\begin{array}{c}\text { Ion ration } \\
\text { average }\end{array}$ & $\begin{array}{c}\text { Ion ratio } \\
\mathrm{CV} \%\end{array}$ & $\begin{array}{l}\text { Samples } \\
\text { fulfilling } \\
\text { criteria }\end{array}$ \\
\hline Medroxyprogesterone acetate & 2.86 & 7 & 100 \\
\hline Megestrol acetate & 0.71 & 7 & 100 \\
\hline Chlormadinone acetate & 1.16 & 10 & 88 \\
\hline Melengestrol acetate & 1.45 & 11 & 94 \\
\hline Testosterone & 1.25 & 7 & 98 \\
\hline epi-Testosterone & 1.18 & 7 & 99 \\
\hline$\alpha$-Boldenone & 1.34 & 5 & 100 \\
\hline$\beta$-Boldenone & 1.16 & 8 & 100 \\
\hline Methylboldenone & 1.53 & 6 & 100 \\
\hline Methyltestosterone & 1.48 & 7 & 98 \\
\hline$\alpha$-Trenbolon & 0.25 & 13 & 95 \\
\hline$\beta$-Trenbolon & 0.85 & 13 & 86 \\
\hline$\alpha$-Nortestosterone & 1.28 & 12 & 96 \\
\hline$\beta$-Nortestosterone & 1.50 & 13 & 83 \\
\hline Androstenedione & 1.40 & 6 & 95 \\
\hline Altrenogest & 0.82 & 5 & 100 \\
\hline Clostebolacetate & 0.95 & 15 & 70 \\
\hline
\end{tabular}

